\title{
Effect of freezing with oscillating magnetic fields on the physical and sensorial characteristics of mango (Mangifera indica L. cv. 'Kent')
}

\section{Efeito de congelamento usando campos magnéticos oscilantes nas características físicas e sensoriais de manga \\ (Mangifera indica L. cv. 'Kent')}

\author{
Enzo Aldoradin Puza1* (D), Frank Esteban Cuba Mayo', José Miguel Alemán Polo, \\ Angel Perea De la Matta², Javier Sánchez Espinoza², Javier Castillo Alva² \\ ${ }^{1}$ Instituto Tecnologico de la Produccion, Callao - Peru \\ ${ }^{2}$ Instituto del Mar del Peru, Callao - Peru
}

*Corresponding author: Enzo Aldoradin Puza, Instituto Tecnologico de la Produccion, Callao, Carretera a

Ventanilla, km 5.2, Callao, Callao 01 - Peru, e-mail: ealdoradin@itp.gob.pe, enzo_499@hotmail.com

Cite as: Aldoradin-Puza, E., Cuba-Mayo, F. E., Aleman-Polo, J. M., Perea-De la Matta, A., Sanchez-Espinoza, J., \&

Castillo-Alva, J. (2019). Effect of freezing with oscillating magnetic fields on the physical and sensorial

characteristics of mango (Mangifera indica L. cv. 'Kent'). Brazilian Journal of Food Technology, 22, e2018169.

https://doi.org/10.1590/1981-6723.16918

\begin{abstract}
Freezing using oscillating magnetic fields (OMF), was developed and is marketed to overcome drawbacks that normally occur in conventional freezing, which affect firmness, colour, taste, and drip loss in frozen-thawed foods. In order to verify the aforementioned advantages, the effect of freezing using OMF on cubes of mango (Mangifera indica L. cv. 'Kent') was evaluated. The cubes were frozen at $-30^{\circ} \mathrm{C}$ for $35 \mathrm{~min}$ with OMF set at $0,30 \%, 50 \%, 75 \%$ and $100 \%$, and then immediately thawed at room temperature $\left(25^{\circ} \mathrm{C}\right)$ for $70 \mathrm{~min}$. The frozen-thawed mango cubes showed cell wall breakage, presumably due to the formation of ice crystals. Likewise, the frozen-thawed cubes were less firm $(p<0.05)$ than fresh mango cubes (with both cubes having come from the same specimen), as determined using a texturometer and sensory evaluation. Drip loss ranged from $2.45 \%$ to $4.15 \%$ in the frozen-thawed mango. Freezing using OMF with a Cells Alive System (CAS) freezer caused negative changes to the thawed mango, mainly a decrease in firmness, with results similar to those reported elsewhere using conventional freezing.
\end{abstract}

Keywords: Fruit; Freezing; Oscillating magnetic fields; Firmness; Histology.

\section{Resumo}

O congelamento usando campos magnéticos oscilantes (OMF) foi desenvolvido e é comercializado para superar as desvantagens que normalmente ocorrem no congelamento convencional, que afeta a firmeza, a cor, o sabor e a perda por gotejamento em alimentos congelados e descongelados. A fim de verificar as vantagens acima mencionadas, avaliamos o efeito do congelamento usando o OMF em cubos de manga (Mangifera indica L. cv. 'Kent'). Os cubos foram congelados a $-30{ }^{\circ} \mathrm{C}$ durante $35 \mathrm{~min}$ com OMF ajustado a 0, 30\%, 
$50 \%, 75 \%$ e $100 \%$ e, depois, imediatamente descongelados à temperatura ambiente $\left(25^{\circ} \mathrm{C}\right)$ durante 70 min. Cubos de manga descongelados mostraram quebra na parede celular, presumivelmente devido à formação de cristais de gelo. Da mesma forma, os cubos congelados e descongelados apresentaram menor firmeza $(p<0,05)$ que os cubos de manga fresca (com ambos os cubos provenientes do mesmo espécime), conforme determinado pelo texturômetro e pela avaliação sensorial. A perda por gotejamento variou de 2,45\% a 4,15\% em manga descongelada. Congelar usando OMF com um congelador do tipo Cells Alive System (CAS) causou mudanças negativas na manga descongelada, principalmente uma diminuição na firmeza, com resultados semelhantes aos relatados em outros estudos usando o congelamento convencional.

Palavras-chave: Fruta; Congelamento; Campos magnéticos oscilantes; Firmeza; Histologia.

\section{Introduction}

Freezing is a traditional method of food preservation used worldwide that consists of three stages: cooling the product to its freezing point (pre-cooling stage), removing the latent heat of crystallization (phase transition stage), and finally, cooling the product to the final storage temperature (tempering stage). The crystallization phase involves the conversion of water to ice crystals, a key step in determining the quality of the frozen product (Kiani \& Sun, 2011). However, freezing is not suitable for all foods, and can cause physical and chemical changes in some foods that are perceived to reduce the quality of either the thawed material or the final product (Rodríguez et al., 2017). Conventional freezing cools foods below $-18{ }^{\circ} \mathrm{C}$, and can affect firmness, colour and taste, while causing the formation of drip loss due to the mechanical stress brought on by the formation of ice crystals and the volume increase in the frozen product, thus damaging membranes and cell walls. These changes may be observed and evaluated in thawed vegetables (Rinaldi et al., 2015) and fruits (Otero et al., 2000; Sirijariyawat \& Charoenrein, 2012; Charoenrein \& Owcharoen, 2016), leading to drip loss and poor texture properties (Pham, 2008; Terefe \& Versteeg, 2011).

Due to these drawbacks of conventional freezing, several innovations in freezing have been developed using electric fields (Xanthakis et al., 2013), microwaves (Xanthakis et al., 2014), magnetic fields (Owada, 2007), high pressure (Otero et al., 2000) etc. One of these innovations is the Cells Alive System (CAS), which was patented and is marketed by the ABI Corporation, Ltd. (Chiba, Japan). CAS uses oscillating magnetic fields (OMF) during the freezing process, supposedly offering a process where a product can be frozen in such a way as to "approximate the quality of a fresh product" once thawed (Owada and Kurita, 2001; cited by Purnell et al., 2017). The CAS consists of a conventional fast freezing system, together with a system of weak frequency electromagnetic waves. According to Owada (2007), CAS uses induction coils in order to produce OMF in the range of $0.1 \mathrm{mT}$ to $100 \mathrm{mT}$; and permanent magnets to generate a static magnetic field (SMF) from $0.1 \mathrm{mT}$ to $1000 \mathrm{mT}$. It has been suggested that applying OMF to a food in the range of $50 \mathrm{~Hz}$ to $5 \mathrm{MHz}$ while freezing will supress the nucleation of ice crystals (such a high OMF and frequency could not be found in any study, such as those carried out by Otero et al., 2016a; Purnell et al., 2017 and Rodríguez et al., 2017), while super-cooling can be achieved without the nucleation of ice crystals down to $-10^{\circ} \mathrm{C}$. This is said to prevent cell damage and maintain the freshness of the food. In other words, the melting point of pure water is $0{ }^{\circ} \mathrm{C}$ at atmospheric pressure. If water is cooled, then it remains in the liquid state well below the melting point, before nucleation occurs. This phenomenon is called super-cooling (Kim et al., 2014), and it is this phenomenon that is said to underlie the operation of the CAS. In industrial practice, only two methods have been introduced for super-cooling: first, using high pressure (such as 2000 times the atmospheric pressure); and second, using antifreeze proteins. Nevertheless, these methods pose problems due to cost or the antipathy to additives (Kim et al., 2014). James et al. (2015) froze fresh garlic bulbs and evaluated the degree of super-cooling on the freezing curve using different CAS settings. At $-20{ }^{\circ} \mathrm{C}$, they indicated that freezing under the different $\mathrm{OMF}$ conditions had little significant effect on the freezing characteristics, and super-cooling is more likely to occur in garlic bulbs frozen from an initial ambient $\left(21^{\circ} \mathrm{C}\right)$ state than those 
frozen from an initial chilled $\left(4{ }^{\circ} \mathrm{C}\right)$ state. However, they did not evaluate other characteristics, such as drip loss and/or texture.

There are advertisements for CAS in the company's website (ABI Co Ltd., 2018), and several videos about the advantages of CAS are available on the internet with regard to the freezing of meat, fruit, vegetables and seafood products. In this regard, several studies have been published, e.g., Yamamoto et al. (2005) froze chicken breast samples in a CAS freezer at $-45^{\circ} \mathrm{C}$ for at least $60 \mathrm{~min}$, and then stored them for one week and for six months. They also froze these samples using conventional rapid freezing $\left(-45^{\circ} \mathrm{C}\right)$ and slow freezing $\left(-20^{\circ} \mathrm{C}\right)$ in order to compare with CAS. They concluded that the electric magnetic field (EMF) freezing at $30 \mathrm{~Hz}$ was a better freezing method for six-month-stored chicken breasts, although there was not much effect of the different freezing methods on the one-week-stored samples.

Studies such as that of Purnell et al. (2017) froze cylindrical samples of apples and potatoes under different conditions using a CAS at $-30{ }^{\circ} \mathrm{C}$ and $-45^{\circ} \mathrm{C}$ for at least $35 \mathrm{~min}$. One part was thawed immediately after freezing for evaluation. Erikson et al. (2016) froze cod immediately after killing with a CAS, conventional air blast and in a cold storage room without forced convention air. Rodríguez et al. (2017) froze fresh pork loin in a CAS at $-30{ }^{\circ} \mathrm{C}$ for at least $60 \mathrm{~min}$. and stored it in a chest freezer for 21 to 27 days, after which the samples were evaluated. Otero et al. (2016a) froze fresh crabstick portions at different CAS settings at $-25^{\circ} \mathrm{C}$ for at least $100 \mathrm{~min}$, evaluating part of each treatment after one day, and the rest after 1, 3, 6, 9 and 12 months. In the aforementioned studies, drip loss, colour, firmness, diameter, length, water-holding capacity, whiteness and other tests were carried out, with the results not supporting the claims made by the patent and by the marketing material, that OMF-assisted freezing substantially improved the freezing process of foodstuffs. Thus, CAS freezing did not avoid quality losses in the samples.

According to the patent (Owada, 2007), the CAS offers OMF from $0.1 \mathrm{mT}$ to $100 \mathrm{mT}$, and frequencies from $50 \mathrm{~Hz}$ to $5 \mathrm{MHz}$. However, studies carried out by Otero et al. (2016a), Purnell et al. (2017) and Rodríguez et al. (2017), all measured different levels of OMF in different places using a CAS, and registered OMF values as low as $2 \mathrm{mT}$ and $60 \mathrm{~Hz}$. However, it is uncertain what the effects of extremely low strength of the frequently applied MFs may have on a substance with low magnetic susceptibility, such as water. As such, this mechanism is established in the patent, but has not been scientifically proven (Otero et al., 2016b). It may be necessary to employ stronger magnetic fields such as that used by Xanthakis et al. (2014), who designed an experimental prototype, used together with other devices such as a microwave and freezer, to freeze pork tenderloin samples, reporting less damage to the meat microstructure as compared to conventional freezing, although they did not carry out a sensory evaluation.

Mango (Mangifera indica L.) is a tropical fruit that grows mainly in Mexico, India, and Brazil (Sistema Integrado de Información de Comercio Exterior, 2017). It is appreciated worldwide by consumers for its characteristic firmness and taste (Dea et al., 2013). In international trade, one of the presentations of this fruit is as frozen mango cubes, a ready-to-eat product (Comisión de Promoción del Perú para la Exportación y el Turismo, 2014). Mango was initially chosen as the object of this study since the industry in northern Peru has experienced some problems in the freezing process for mango cubes (obtaining less firmness in the thawed mango). We realized that the effect of OMF on this sample could be evaluated immediately (through instrumental and sensory testing) after freezing, without any storage or other processes (i.e., boiling) as required for meat products.

The hypothesis of this study was that the use of OMF from the CAS during the mango freezing process would maintain the characteristics of fresh mango after the freeze-thaw process, overcoming the defects reported for conventional freezing. As such, the objective of the present study was to evaluate the effects of freezing using OMF on the physical and sensorial characteristics of mango cubes (Mangifera indica L. cv. 'Kent'), comparing them in the fresh and thawed states immediately after freezing, in order to establish whether any possible changes observed in the thawed mango were caused by freezing. 


\section{Materials and methods}

\subsection{Sample preparation}

Whole mature mangos (M. indica L. cv. 'Kent') $(n=25)$ were acquired from Lima's wholesale fruit market (Lima, Peru). The specimens were transported at room temperature $\left(25^{\circ} \mathrm{C}\right)$ to the Instituto Tecnológico de la Producción (ITP) in El Callao (Peru), where they were evaluated immediately. The means and standard deviations (SD) for the mass, height and width of the whole mangos was $621(48) \mathrm{g}, 11.4(0.36) \mathrm{cm}$ and 9.4 $(0.32) \mathrm{cm}$, respectively.

According to the proximate analysis, the mango cubes contained $81.5 \%$ moisture, $0.95 \%$ protein, $0.5 \%$ fat, $0.6 \%$ ash, and $16.5 \%$ carbohydrate. These analyses were carried out using FAO methods (Food and Agriculture Organization, 1996). In addition, the total soluble solids (TSS) were $18.5^{\circ} \mathrm{Brix}$; the $\mathrm{pH}$ value (1:9 mango/distilled water ratio) was 4.05 ; and the titratable acidity (TA) was $0.37 \%$ (expressed as citric acid). The latter analyses were carried out according to Rincon \& Kerr (2010).

Each mango (from the equatorial zone) was washed, peeled and cut into cubes measuring $2.5 \mathrm{~cm}$ per side, obtaining twelve cubes for each mango.

\subsection{CAS}

This study used a Cells Alive System (CAS) (Model CAS-30B, ABI Corporation Ltd., Chiba, Japan) similar to the one employed by Otero et al. (2016a). The equipment has 10 aluminium trays (area of $40 \mathrm{~cm}$ by $60 \mathrm{~cm}$ each) arranged vertically, where Tray 1 is located at the top and Tray 10 at the bottom. This CAS consists of a forced air freezer (using two fans), combined with a system of weak oscillating magnetic fields (OMF) and static magnetic fields (SMF). These parameters were reported in Otero et al. (2016a). The CAS measures $2.4 \mathrm{~m}$ (height) x $1.95 \mathrm{~m}$ (width) x $2.17 \mathrm{~m}$ (length). Several parameters can be set on the CAS setting screen, such as: i) cooling temperature, ii) cooling fan, iii) CAS temperature, iv) CAS fan, v) CAS energy and vi) CAS time, where OMF is set as the CAS energy, ranging from 30 to $100 \%$ (at intervals of $1 \%$ ). As such, values below $30 \%$ could not be set for the CAS. Based on the preliminary tests, a temperature of $30{ }^{\circ} \mathrm{C}$ was established as that normally used by industry, as well as in some studies (Otero et al., 2016a; Purnell et al., 2017), while the "Cooling FAN" and "CAS FAN" values used were 50 and 30\%, respectively. Using these conditions, a significant decrease in firmness of the thawed mango was perceived by touch and taste after freezing. Therefore, in the present study only the CAS energy was varied, keeping the other parameters constant on the setting screen. The freeze-thaw time was set using a wireless thermocouple (Data Tracer ${ }^{\mathbb{B}}$ model MT3, USA), establishing a freezing time of $35 \mathrm{~min}$ (sufficient to reach $-25^{\circ} \mathrm{C}$ ) and a thawing time of $70 \mathrm{~min}$ (sufficient to reach $+8^{\circ} \mathrm{C}$ ), both data not shown. The thawing process consisted of placing all frozen mango cubes at room temperature $\left(25^{\circ} \mathrm{C}\right)$ without a fan.

Unfortunately, at the time of the study some details of the OMF were not provided by ABI and the authors lacked some necessary measuring equipment such as a teslameter or oscilloscope to measure the OMF and frequency. As such, the main objective was to observe and evaluate the changes in firmness, drip loss and other tests of the frozen-thawed fresh mango at different OMF values (established by ABI). However, Otero et al. (2016a), Purnell et al. (2017) and Rodríguez et al. (2017) were able to measure different intensities of OMF (that the equipment was capable of reaching) in different places within the CAS freezer, a maximum of $2 \mathrm{mT} \mathrm{OMF}$ and $60 \mathrm{~Hz}$ being recorded using this equipment.

\subsubsection{Freezing curve analysis}

For each specific experiment, five whole mangos were used. The CAS freezer was previously cooled to $30{ }^{\circ} \mathrm{C}$ (set as "Cooling temperature" on the setting screen) for at least $2 \mathrm{~h}$. 
Freezing using OMF (shown as CAS energy on the setting screen) was set at $30 \%, 50 \%, 75 \%$ and $100 \%$. In addition, $0 \%$ was considered for OMF, keeping this function (on off) on the equipment control panel in order to simulate conventional freezing in the CAS freezer. For each batch frozen in the CAS freezer, mango cubes $(n=40)$ were placed on Tray 5 (as per the numeration of Otero et al., 2016a), where Tray 1 and Tray 10 are located at the top and the bottom, respectively. The tip of a thermistor (Data Tracer ${ }^{\circledR}$, type MPIII, model $7500 \mathrm{~T}$, USA) was inserted in a mango cube $(n=5)$ at the approximate geometric centre to measure the core temperatures during the freezing process. The sample temperature was recorded at a resolution of $0.001{ }^{\circ} \mathrm{C}$ at $15 \mathrm{~s}$ intervals during $35 \mathrm{~min}$ for the freezing process. Immediately after, all the cubes were thawed on the tray, by placing them at room temperature $\left(25^{\circ} \mathrm{C}\right.$ ) for $70 \mathrm{~min}$ (to reach $+8{ }^{\circ} \mathrm{C}$, according to the preliminary test).

The environmental air temperatures were recorded for each experiment by two thermistors, set at $-30{ }^{\circ} \mathrm{C}$. The air temperature typically ranged from $-29^{\circ} \mathrm{C}$ to $-31^{\circ} \mathrm{C}$ (data not shown).

\subsection{Physical analysis}

\subsubsection{Firmness}

Since the firmness varies among mango specimens, the firmness of the fresh and thawed mango cubes was assessed using the same specimen, in order to avoid this variability. The firmness of the fresh mango cubes $(n=8)$ and freeze-thaw cubes $(n=8)$ was analysed for each CAS setting batch. Firmness was determined using the compression function in a texturometer (Brookfield, model CT3-1500, USA) equipped with a flat-ended cylindrical plunger with an $8 \mathrm{~mm}$ diameter at $0.5 \mathrm{~mm} \mathrm{~s}^{-1}$. This texturometer reports the maximum firmness $(\mathrm{N})$ as related to the penetration depth $(\mathrm{mm})$ in the sample, and hence the penetration depth was set at $6 \mathrm{~mm}$.

Due to the slightly convex surface (close to the skin) of the mango cubes, prior to carrying out the firmness analysis, a layer measuring up to approximately $3 \mathrm{~mm}$, close to the skin, was removed from each cube, in order to achieve a flat contact between the plunger and the surface of the mango cube.

\subsubsection{Drip loss}

After freezing, for each mango cube batch frozen at the different CAS settings tested in this study, fresh mango cubes $(n=12)$ were randomly chosen and weighed, subsequently frozen $\left(-30^{\circ} \mathrm{C}\right.$ for $\left.35 \mathrm{~min}\right)$, and then thawed by placing them at room temperature for $70 \mathrm{~min}$ to reach $+8{ }^{\circ} \mathrm{C}$ at the cube centre. Exudate on the surface of the mango cube was dried using tissue paper and weighed. The drip loss (DL) from each mango cube was determined from the difference in weight and expressed as the percent of mass loss (Sirijariyawat \& Charoenrein, 2012), according to Equation 1:

$$
D L(\%)=\frac{\left(M_{f h}-M_{t h}\right)}{M_{f h}} \times 100
$$

Where $M_{f h}$ and $M_{t h}$ are the masses ( $\mathrm{g}$ ) of the fresh and thawed mango cubes, respectively.

\subsection{Histological analysis}

Slices ( $0.3 \times 0.5 \times 0.5 \mathrm{~cm})$ of fresh and frozen mango cubes (coming from the same mango) were cut using a surgical blade (feather) and immersed for 4 days in a fixative solution composed of ethanol (50\%), acetic acid (5\%), formaldehyde (10\%) and water (35\%) (Megías et al., 2016). The fixed samples were sent to the Laboratorio de Biología Reproductiva at the Instituto del Mar del Peru (IMARPE) and successively dehydrated in ethanol at concentrations of $70 \%, 80 \%, 90 \%$ and $100 \%$, then immersed in xylene $(2 \mathrm{~h})$ and infiltrated with paraffin at $60{ }^{\circ} \mathrm{C}(2 \mathrm{~h})$. Each sample was then embedded in paraffin to trap them in paraffin 
blocks, and cooled for $12 \mathrm{~h}$ overnight. Slices ( $7 \mu \mathrm{m}$ thickness) were acquired from the paraffin block samples using a semiautomatic microtome (Leica microtome, model 2245, Germany) and then stained using a hematoxylin-eosin system (Buitrón et al., 2011). These preparations were observed under the microscope (Leica DM2000LED, Germany).

\subsection{Sensory evaluation}

The triangular test is a sensory discrimination test that consists of presenting 3 samples ( 3 mango cubes in this study) to a single panellist, where two samples are identical and one is different according to one attribute, and the panellist is asked to identify the different sample (Anzaldúa-Morales, 1994).

Firmness in the fresh and thawed mango cubes (taken from the same mango) was assessed in a sensory evaluation by biting, and analysed by 15 semi-trained panellists using a triangular test. Each panellist evaluated 3 mango cubes, where i) one of them might be fresh mango while the other two were thawed mango; or ii) one cube might be thawed mango and the other two fresh mango cubes. One of these alternatives was randomly distributed to each panellist. According to Anzaldúa-Morales (1994), in order to obtain a significance level of 5\% for this test, i.e., to find a statistical difference in firmness between the fresh and thawed mango cubes, at least 9 of the 15 panellists had to identify the different sample.

\subsection{Data analysis}

The statistical analysis of the data was carried out using SPSS Statistics software (version 18) (IBM Corp., NY, USA). Shapiro-Wilk's test was used to evaluate normality. The data were evaluated using a one-way analysis of variance (ANOVA), followed by Tukey's post-hoc test to group the results according to different OMF. The results were expressed as the mean and standard deviation (SD) and the significance threshold set at 0.05 for all tests.

\section{Results and discussion}

\subsection{Freezing curve analysis}

The evolution of temperature based on the freezing time of the mango cubes in the CAS freezer at different levels of oscillating magnetic field (OMF) was registered (Figure not shown). The 3 phases of the freezing process (pre-cooling, crystallization and tempering phase) appeared for all the OMF levels. All the experiments showed a crystallization phase that at least indicated the formation of ice crystals of some length, which might affect food quality.

The mean and SD values of the freezing parameters using OMF in the CAS freezer at $-30{ }^{\circ} \mathrm{C}$ are shown in Table 1 . There was a significant difference $(p<0.05)$ in the time and rate of the complete freezing and crystallization phase at the different OMF levels. The complete freezing of the mango cubes took from 16.41 to $22.38 \mathrm{~min}$, for 100 and $50 \% \mathrm{OMF}$, respectively, to reach $-18{ }^{\circ} \mathrm{C}$ at the geometric centre; while the crystallization phase took between 4.10 and $7.30 \mathrm{~min}$ for 0 and $50 \% \mathrm{OMF}$, respectively, to go from $-1{ }^{\circ} \mathrm{C}$ to $-5^{\circ} \mathrm{C}$. 
Table 1. Freezing parameters using OMF in a CAS freezer at $-30{ }^{\circ} \mathrm{C}(n=5)$.

\begin{tabular}{|c|c|c|c|c|c|}
\hline \multirow{2}{*}{ Parameter } & \multicolumn{5}{|c|}{ Oscillating Magnetic Field (OMF) * } \\
\hline & $\mathbf{0}$ & $30 \%$ & $50 \%$ & $75 \%$ & $100 \%$ \\
\hline \multicolumn{6}{|c|}{ Complete Freezing $\left(+17^{\circ} \mathrm{C}\right.$ to $\left.-18^{\circ} \mathrm{C}\right)$} \\
\hline Time (min) & $17.50(1.54)^{\mathrm{a}, \mathrm{b}}$ & $19.20(1.30)^{\mathrm{b}}$ & $22.38(0.48)^{\mathrm{c}}$ & $22.17(1.63)^{\mathrm{c}}$ & $16.41(1.28)^{\mathrm{a}}$ \\
\hline Rate $\left({ }^{\circ} \mathrm{C} / \mathrm{min}\right)$ & $2.01(0.17)^{\mathrm{a}, \mathrm{b}}$ & $1.83(0.12)^{\mathrm{a}, \mathrm{d}}$ & $1.56(0.03)^{\mathrm{c}}$ & $1.59(0.12)^{\mathrm{c}, \mathrm{d}}$ & $2.14(0.17)^{b}$ \\
\hline \multicolumn{6}{|c|}{ Crystallization Phase $\left(-1^{\circ} \mathrm{C}\right.$ to $\left.-5^{\circ} \mathrm{C}\right)$} \\
\hline Time (min) & $4.10(0.37)^{\mathrm{a}}$ & $4.86(0.31)^{\mathrm{a}, \mathrm{b}}$ & $7.30(0.93)^{\mathrm{d}}$ & $5.92(0.58)^{\mathrm{b}, \mathrm{c}}$ & $6.33(1.09)^{\mathrm{c}, \mathrm{d}}$ \\
\hline Rate $\left({ }^{\circ} \mathrm{C} / \mathrm{min}\right)$ & $0.98(0.09)^{\mathrm{c}}$ & $0.83(0.06)^{b, c}$ & $0.56(0.08)^{\mathrm{a}}$ & $0.68(0.06)^{\mathrm{a}, \mathrm{b}}$ & $0.65(0.11)^{\mathrm{a}}$ \\
\hline
\end{tabular}

$(*)$ Different letters in superscript in results in the same row indicate significant difference $(p<0.05)$.

The crystallization phase in conventional food freezing generally occurs between 0 and $-5^{\circ} \mathrm{C}$ (Miyawaki, 2001), and it is well known that a short period of this phase is recommended in order to allow for the formation of numerous small ice crystals and to avoid the loss of food quality (Pham, 2008). On the other hand, several factors may influence the quality of food freezing, such as the nature of the food, presentation before freezing (blocks or individual portions), set temperature of the freezing medium, quantity of food (load) put into the freezer, freezer type and cooling capacity, and others. However, these variables can be summarized using the rate of freezing to compare different results under different conditions of freezing and omit the possible interference factors mentioned. Accordingly, the rate of freezing in the present study ranged from 1.56 to $2.14{ }^{\circ} \mathrm{C} / \mathrm{min}$ for $50 \%$ and $100 \%$ OMF, respectively (Table 1). Likewise, other studies using OMF such as that of Purnell et al. (2017), obtained a rate of freezing (values calculated by the present authors) of 0.80 to $1.01{ }^{\circ} \mathrm{C} / \mathrm{min}$ for apple and 0.89 to $1.04{ }^{\circ} \mathrm{C} / \mathrm{min}$ for potato. Rodríguez et al. (2017) indicated a rate of freezing of 1.52 to $2.22{ }^{\circ} \mathrm{C} / \mathrm{min}$ for pork loin. Despite the different rates of freezing in the studies cited (with different freezing conditions), they found no significant effect due to the use of different levels of OMF on their samples. It is well known that fast freezing rates produce a large number of small ice crystals that cause less damage. However, to the authors' knowledge, there is no published freezing rate value that can be used to compare or recommend for application in the freezing of foods. As such, specific people or industries may freeze different presentations using individual quick freezing (IQF) for blocks (from 0.5 to $20 \mathrm{~kg}$ ) of mango, fish, meat, etc., and the different masses frozen will obviously affect the final quality of the frozenthawed food. This reflects the different durations of the crystallization phase, and thus, the formation of different lengths of ice crystals, causing cell breakage.

\subsection{Firmness}

The firmness and depth of both fresh and frozen-thawed mango cubes (taken from the same specimen) were measured using a compression test (Figure 1). In Figure 1A, the results for all the measurements showed that the firmness of the thawed mango cubes decreased significantly $(p<0.05)$ after freezing (using different levels of OMF) as compared to the fresh mango cubes, decreasing their firmness by $63 \%$ to $77 \%$ for $100 \%$ and $0 \% \mathrm{OMF}$, respectively. The decrease in firmness using different levels of OMF in the CAS freezer were similar to other studies carried out using cryogenic freezing, where firmness decreased by $66 \%$ for Nam Dok Mai mango (frozen at $-40{ }^{\circ} \mathrm{C}$ and stored for one month) (Sirijariyawat \& Charoenrein, 2012); and $62 \%$ for Kent mango (frozen at $-50^{\circ} \mathrm{C}$ and stored for 14 days) (Sirijariyawat et al., 2012), respectively. In these latter studies, the decrease in firmness could be attributed to the effect of freezing and the effect of storage. However, in the present study, the loss of firmness occurred mainly due to the effect of freezing using a CAS freezer, given that the thawed mango cubes were evaluated immediately, without any storage period.

On the other hand, based on the texturometer used, which reports a maximum firmness $(\mathrm{N})$ related to penetration depth $(\mathrm{mm})$ in the mango cube, the depth penetrated by the texturometer probe in the thawed mango was recorded in correlation with its firmness as reported in Figure 1B. According to all the 
measurements, the depth in the thawed mango cubes was greater $(p<0.05)$ than in the fresh state (Figure 1B), which ranged from $50 \%$ to $90 \%$ for 0 and $30 \%$ OMF, respectively.

This significant decrease in firmness and increase in penetration depth was also observed in immature mango (data not shown).
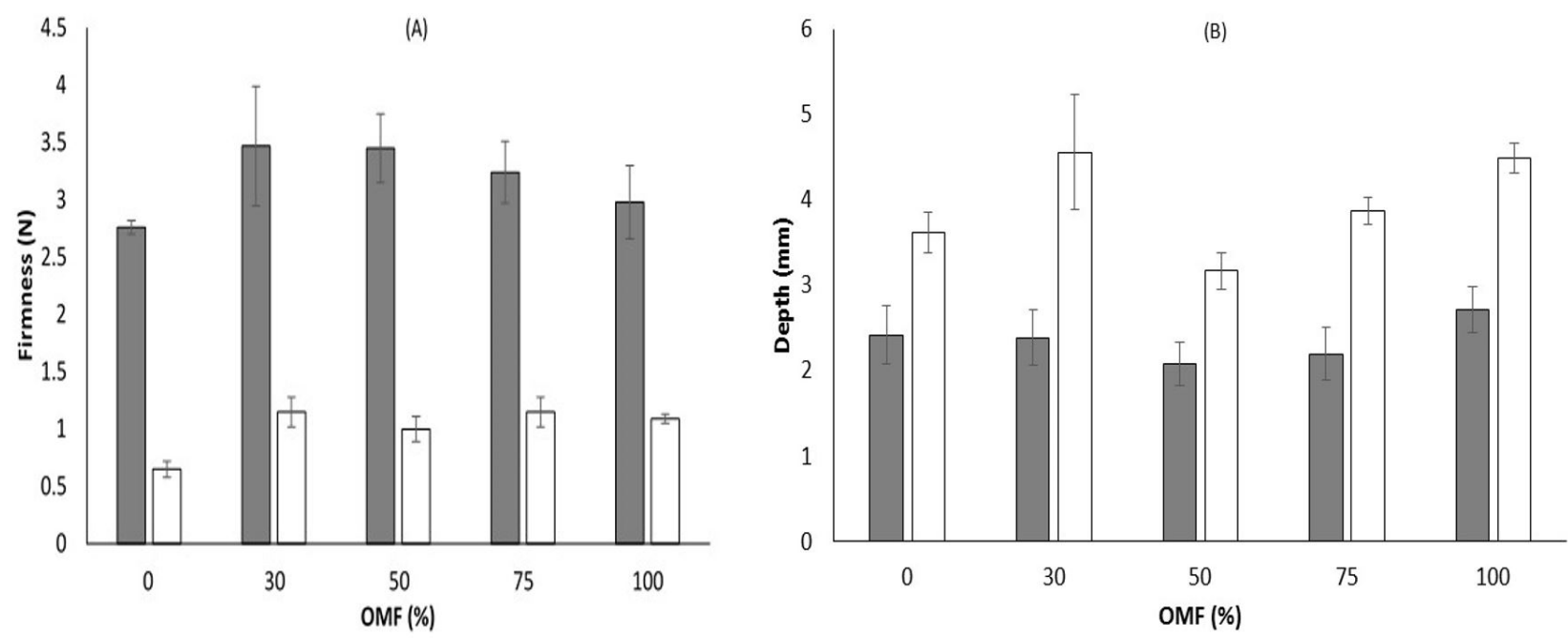

Figure 1. Firmness (A) and depth (B) of mango cubes in the fresh ( $\square$ ) ad frozen-thawed ( $\square$ ) st ate.

These drastic changes in the firmness and depth of the frozen-thawed mango cubes as compared to fresh mango may be attributed to the nature of the cell structure of these plants, which are composed of semi-rigid, polyhedral cells containing cellulosic cell walls bound by a pectinaceous middle lamella and often including an extensive network of air spaces (Otero et al., 2000). In summary, fresh mango presented greater firmness than frozen-thawed mango, a difference that was also clearly perceived during the sensory evaluation (see 3.5).

\subsection{Drip loss}

The drip loss of the freeze-thawed mango cubes after being subjected to different levels of OMF is shown in Table 2. In all but one instance (30\%), there were no significant effects of the OMF on drip loss for the freeze-thawed mango cubes. Drip loss fluctuated from $2.45 \%$ to $4.15 \%$, which corresponded to $30 \%$ and $0 \%$ OMF, respectively. The results found in the present study were lower than those reported (both using a cryogenic freezer) for the mango variety Nam Dok Mai of $22.2 \%$ (frozen at $-40{ }^{\circ} \mathrm{C}$ and stored for 7 days) (Charoenrein \& Owcharoen, 2016) and $18.7 \%$ (frozen at $-40{ }^{\circ} \mathrm{C}$ and stored for 30 days) (Sirijariyawat \& Charoenrein, 2012). This difference in drip loss as compared to the other studies cited may be explained by the fact that the present mango cubes were thawed immediately after freezing (without any storage). Thus the liquid released from the interior to the exterior of the mango cubes due to damaged fruit cells, may be strictly due to freezing in the CAS freezer. Other studies using OMF for freezing, such as Purnell et al. (2017), found drip loss values for apple and potato which ranged from $9.4 \%$ to $10.5 \%$ and from $10.0 \%$ to $13.7 \%$, respectively (frozen at $-30{ }^{\circ} \mathrm{C}$ and thawed immediately), where they indicated there was no significant difference for the majority of conditions under different levels of OMF. Likewise, the present results, together with those reported by Purnell et al. (2017), indicated that different fruits present different drip losses under the same conditions of freezing and thawing. 
Effect of freezing with oscillating magnetic fields on the physical and sensorial characteristics of mango (Mangifera indica L. cv. 'Kent')

Aldoradin-Puza, E. et al.

Table 2. Drip loss from freeze-thawed mango cubes.

\begin{tabular}{cc}
\hline OMF (\%) & Drip loss (\%)* \\
\hline 0 & $4.15(0.25)^{\mathrm{b}}$ \\
30 & $2.45(0.35)^{\mathrm{a}}$ \\
50 & $4.09(0.45)^{\mathrm{b}}$ \\
75 & $3.88(0.49)^{\mathrm{b}}$ \\
\hline 100 & $3.98(0.54)^{\mathrm{b}}$ \\
\hline
\end{tabular}

$(*)$ Different letters in the superscript in results in the same column indicate significant difference $(p<0.05)$.

\subsection{Histological analysis}

Figure 2 shows a histological section of mango cube after freezing under 50\% OMF. A micrograph of the mango cube shows the cell wall, and the presence of fibre bundles and starch granules, as mentioned by Raymond et al. (1998).

The fresh mango showed integral cell walls (as seen in Figure 2A), whereas the mango frozen using different OMF levels showed ruptured cell walls, presumably due to ice crystals (Figure 2B, provided for reference). In the present study, the hydrolytic enzymatic action that might contribute to some cell wall rupture was considered minimal, since the fixation for this analysis took place immediately after freezing.

(A)

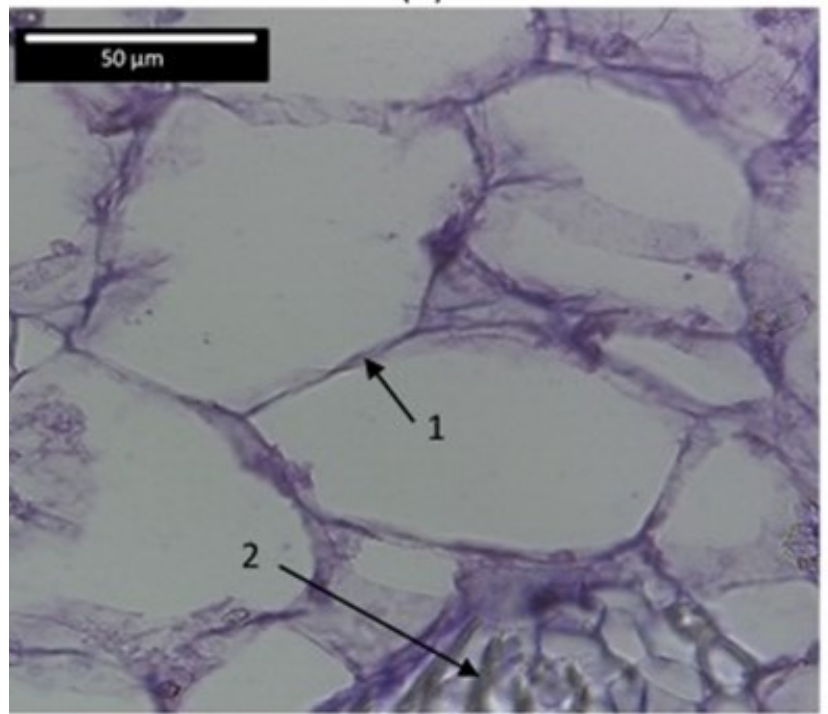

(B)

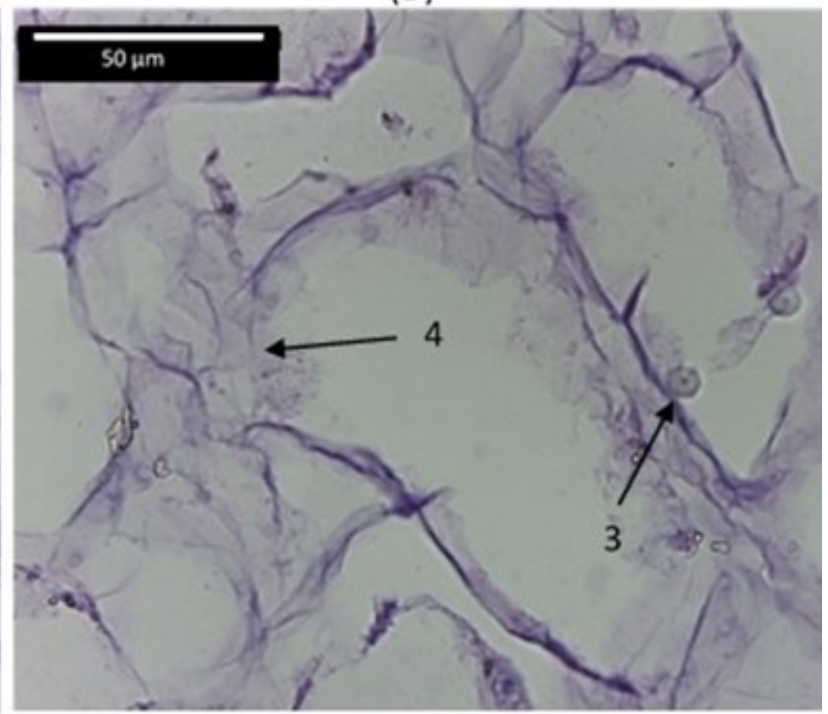

Figure 2. Histological section of mango cube: A) Fresh and B) Frozen (using 50\% OMF). 1) Cell wall. 2) Fibre bundle. 3) Starch granule. 4) Cell wall breakage.

The patent pertaining to electromagnetic freezing claims that the CAS freezer prevents the destruction of food cells (Owada, 2007). However, the results of the histological analysis in the present study on mango cubes showed ruptured cell walls after freezing with the use of OMF, as typically occurs in fruit during conventional freezing (Otero et al., 2000; Sirijariyawat et al., 2012; Charoenrein \& Owcharoen, 2016). Thus, the results of the present study do not support the claims of the above-mentioned patent.

Otero et al. (2000) froze a whole peach and mango using air-blast freezing $\left(-40^{\circ} \mathrm{C}\right)$, cryogenic freezing using the evaporation of liquid $\mathrm{N}_{2}$, and high-pressure-shift freezing (HPSF) $\left(-40{ }^{\circ} \mathrm{C}\right.$ and $\left.200 \mathrm{MPa}\right)$, primarily evaluating the microstructure and determining the freezing rate. They found that the HPSF technique was the freezing method that best preserved the vegetable microstructure. Apparently, that freezing technique offered advantages for freezing fruits, but the authors did not evaluate the firmness of the fruits by using either instrumental or sensory methods. Firmness is a very important measurement to evaluate the effectiveness of a 
freezing method in order to avoid any incomplete or misleading information or advertisements, as occurred with the CAS freezer several years ago, because this characteristic will ultimately be perceived by the consumers.

\subsection{Sensory evaluation}

Table 3 indicates the results of the sensory evaluation of firmness, comparing the samples of fresh and frozen-thawed mango cubes according to the triangular test. These results indicated a significant difference $(p<0.05)$; that is to say, according to the firmness, all the panellists were able to identify or differentiate the fresh mango cubes from the frozen-thawed mango cubes. All the panellists indicated that the frozen-thawed mango cubes were less firm than the fresh ones. In addition, the panellists indicated that the frozen-thawed mango cubes could be easily broken apart using the pressure of the tongue against the palate, without the use of the teeth. The flavour and colour attributes of the thawed mango cubes were similar to those of the fresh ones (data not shown).

Table 3. Sensory evaluation of firmness using the triangular test between fresh and frozen-thawed mango cubes.

\begin{tabular}{ccc}
$\begin{array}{c}\text { Participating panellists } \\
(n)\end{array}$ & $\begin{array}{c}\text { Panellists with the correct answer } \\
(n)\end{array}$ & $\begin{array}{c}\text { Panellists with the incorrect answer } \\
(n)\end{array}$ \\
\hline 15 & 15 & 0 \\
\hline
\end{tabular}

\subsection{Overall}

In the present study, the crystallization phase occurred during mango freezing using different levels of OMF in the CAS freezer. This allowed for the formation of ice crystals of a certain length that caused cell wall breakage (Figure 2B). In all experiments, the frozen-thawed mango cubes were noticeably less firm than the fresh ones, as assessed by both an instrumental determination (Figure 1) and sensory evaluation (Table 3). This cell wall breakage allowed for the leaking of fluid from internal to external sites in the mango cubes and was evidenced by drip loss (Table 2).

\section{Conclusions}

According to the results of this study, under the experimental conditions used, the freezing of mango cubes using oscillating magnetic fields (OMF) $(30 \%, 50 \%, 75 \%$ and $100 \%)$ and without OMF $(0 \%)$ in the CAS freezer did not maintain the same characteristics as the fresh mango, as implied in the patent. This study observed cell wall breakage, a decrease in firmness and drip loss in the frozen-thawed mango. These drawbacks are effects that typically occur in the conventional freezing of fruit.

\section{References}

ABI Co Ltd. (2018). Retrieved in 2017, January 15, from http://www.abi-net.co.jp/ Anzaldúa-Morales, A. (1994). La evaluación sensorial de los alimentos en la teoría y la práctica (198 p.). España: Acribia SA. Buitrón, B., Perea, A., Mori, J., Sánchez, J., \& Roque, C. (2011). Protocol for studies on the reproductive process of pelagic and demersal fishes. Informe IMARPE, 38(4), 373-384.

Charoenrein, S., \& Owcharoen, K. (2016). Effect of freezing rates and freeze-thaw cycles on the texture, microstructure and pectic substances of mango. International Food Research Journal, 23(2), 613-620.

Dea, S., Brecht, J. K., Nunes, M. C. N., \& Baldwin, E. A. (2013). Optimal ripeness stage for processing "Kent" mangoes into fresh-cut slices. HortTechnology, 23(1), 12-23. http://dx.doi.org/10.21273/HORTTECH.23.1.12

Comisión de Promoción del Perú para la Exportación y el Turismo - PROMPERÚ (2014). Perfil producto - Mercado: mango en conserva y congelado en EEUU (p. 8). Lima: PROMPERÚ.

Erikson, U., Kjørsvik, E., Bardal, T., Digre, H., Schei, M., Søreide, C., \& Aursand, I. (2016). Quality of Atlantic cod frozen in Cell Alive System, air-blast, and cold storage freezers. Journal of Aquatic Food Product Technology, 25(7), $1001-1020$. http://dx.doi.org/10.1080/10498850.2015.1007542 
Food and Agriculture Organization - FAO. (1996). Food analysis: general techniques additives, contaminants and composition (Food and Nutrition Paper, 14:7, 238 p.). Rome: FAO.

James, C., Reitz, B., \& James, S. J. (2015). The freezing characteristics of garlic bulbs (Allium sativum L.) frozen conventionally or with the assistance of an oscillating weak magnetic field. Food and Bioprocess Technology, 8(3), 702-708. http://dx.doi.org/10.1007/s11947-014-1438-z

Kiani, H., \& Sun, D. W. (2011). Water crystallization and its importance to freezing of foods: A review. Trends in Food Science \& Technology, 22(8), 407-426. http://dx.doi.org/10.1016/j.tifs.2011.04.011

Kim, J., Chun, H. H., Park, S., Choi, D., Choi, S. R., Oh, S., \& Yoo, S. M. (2014). System design and performance analysis of a quick freezer using supercoiling. Journal of Biosystems Engineering, 39(4), 330-335 http://dx.doi.org/10.5307/JBE.2014.39.4.330

Megías, M., Molist, P., \& Pombal, M. A. (2016). Atlas de histología vegetal y animal. Técnicas histológicas. España: Universidad de Vigo.

Miyawaki, O. (2001). Analysis and control of ice crystal structure in frozen food and their application to food processing. Food Science and Technology Research, 7(1), 1-7. http://dx.doi.org/10.3136/fstr.7.1

Otero, L., Martino, M., Zaritzky, N., Solas, M., \& Sanz, P. D. (2000). Preservation of microstructure in peach and mango during high-pressure-shift freezing. Journal of Food Science, 65(3), 466-470. http://dx.doi.org/10.1111/j.1365-2621.2000.tb16029.x

Otero, L., Pérez-Mateos, M., Rodríguez, A. C., \& Sanz, P. D. (2016a). Electromagnetic freezing: effects of weak oscillating magnetic fields on crab sticks. Journal of Food Engineering, http://dx.doi.org/10.1016/j.jfoodeng.2016.12.018

Otero, L., Rodríguez, A. C., Pérez-Mateos, M., \& Sanz, P. D. (2016b). Effects of magnetic fields on freezing: application to biological products. Comprehensive Reviews in Food Science and Food Safety, 15(3), 646-667. http://dx.doi.org/10.1111/15414337.12202

Owada, N. (2007). US Patent 7237400 B2. Washington, DC: U.S. Patent and Trademark Office.

Pham, Q. T. (2008). Advances in food freezing/thawing/freeze concentration modelling and techniques. Nihon Shokuhin Kogakkaishi, 9(1), 21-32. http://dx.doi.org/10.11301/jsfe2000.9.21

Purnell, G., James, C., \& James, S. J. (2017). The effects of applying oscillating magnetic fields during the freezing of apple and potato. Food and Bioprocess Technology, 10(12), 2113-2122. http://dx.doi.org/10.1007/s11947-017-1983-3

Raymond, L., Schaffer, B., Brecht, J. K., \& Crane, J. H. (1998). Internal breakdown in mango fruit: symptomology and histology of jelly seed, soft nose and stem-end cavity. Postharvest Biology and Technology, 13(1), 59-70.

http://dx.doi.org/10.1016/S0925-5214(97)00074-4

Rinaldi, M. M., Vieira, E. A., Fialho, J. F., \& Malaquias, J. V. (2015). Efeito de diferentes formas de congelamento sobre raízes de mandioca. Brazilian Journal of Food Technology, 18(2), 93-101. http://dx.doi.org/10.1590/1981-6723.3414

Rincon, A., \& Kerr, W. L. (2010). Influence of osmotic dehydration, ripeness and frozen storage on physicochemical properties of mango. Journal of Food Processing and Preservation, 34(5), 887-903. http://dx.doi.org/10.1111/j.1745-4549.2009.00404.x

Rodríguez, A. C., James, C., \& James, S. J. (2017). Effects of weak oscillating magnetic fields on the freezing of pork loin. Food and Bioprocess Technology, 10(9), 1615-1621. http://dx.doi.org/10.1007/s11947-017-1931-2

Sistema Integrado de Información de Comercio Exterior - SIICEX. (2017). Retrieved in 2017, February 24, from http://www.siicex.gob.pe/siicex/portal5ES.asp?_page_=172.17100\&_portletid_=sfichaproductoinit\&scriptdo=cc_fp_init\&pproduct $\mathrm{o}=118 \&$ pnomproducto=Mango

Sirijariyawat, A., \& Charoenrein, S. (2012). Freezing characteristics and texture variation after freezing and thawing of four fruit types. Songklanakarin Journal of Science and Technology, 34(5), 517-523.

Sirijariyawat, A., Charoenrein, S., \& Barrett, D. M. (2012). Texture improvement of fresh and frozen mangoes with pectin methylesterase and calcium infusion. Journal of the Science of Food and Agriculture, 92(13), 2581-2586. PMid:22806757. http://dx.doi.org/10.1002/jsfa.5791

Terefe, N. S., \& Versteeg, C. (2011). Texture and microstructure of fruits and vegetables. In R. Cruz (Eds.), Practical food and research. Australia: Food Science and Technology.

Xanthakis, E., Havet, M., Chevallier, S., Abadie, J., \& Le-Bail, A. (2013). Effect of static electric field on ice crystal size reduction during freezing of pork meat. Innovative Food Science \& Emerging Technologies, 20, 115-120. http://dx.doi.org/10.1016/j.ifset.2013.06.011

Xanthakis, E., Le-Bail, A., \& Ramaswamy, H. (2014). Development of an innovative microwave assisted food freezing process. Innovative Food Science \& Emerging Technologies, 26, 176-181. http://dx.doi.org/10.1016/j.ifset.2014.04.003

Yamamoto, N., Tamura, S., Matsushita, J., \& Ishimura, K. (2005). Fracture properties and microstructure of chicken breasts frozen by electromagnetic freezing. Journal of Home Economics of Japan, 56(3), 141-151. 